\title{
Direct Synthesis and Applications of Solid Silylzinc Reagents
}

Revathi Chandrasekaran, Feba Thomas Pulikkottil, Krishna Suresh, Ramesh Rasappan*

The increased synthetic utility of organosilanes motivates researchers to develop a milder and more practical synthetic methods. Silylzinc reagents, which are typically the most functional group tolerant, are notoriously difficult to synthesize because they are obtained by a pyrophoric reaction of silyllithium, particularly $\mathrm{Me}_{3} \mathrm{SiLi}$ itself prepared by the reaction of MeLi and disilane. Furthermore, the dissolved $\mathrm{LiCl}$ in silylzinc may have a detrimental effect. A synthetic method that can avoid silyllithium and involves a direct synthesis of silylzinc reagents from silyl halides is arguably the simplest and economical strategy. We describe for the first time, the direct synthesis of $\mathrm{PhMe}_{2} \mathrm{SiZnI}$ and $\mathrm{Me}_{3} \mathrm{SiZnl}$ reagents by employing a coordinating TMEDA ligand, as well as single crystal XRD structures. Importantly, they can be obtained as solid and stored for longer periods of time. We demonstrate their significance in cross-coupling of various free alkyl/aryl/alkenyl carboxylic acids with broader functional group tolerance and API derivatives. The general applicability and efficiency of solid $\mathrm{Me}_{3} \mathrm{SiZnl}$ are shown in a wide variety of reactions including alkylation, arylation, allylation, 1,4-addition, acylation and more.

\section{Introduction}

Organosilicons are widely utilized in various disciplines ${ }^{1}$ and employed in a broad range of organic transformations. ${ }^{2}$ Traditional silylating agents include silanes $\left(\mathrm{R}_{3} \mathrm{SiH}\right),{ }^{2 \mathrm{a}, 2 \mathrm{~h}}$ disilanes, ${ }^{2 f, 2 l, 3}$, Silylboranes, ${ }^{2 \mathrm{c}, 4}$ electrophilic silyl halides and nucleophilic silyl anions (Figure 1a). While silanes are extensively utilized in hydrosilylations, ${ }^{2 h, 5}$ silyl halides are usually combined with organometallic reagents to forge $\mathrm{C}-\mathrm{Si}$ bond, noteworthy examples are the recently

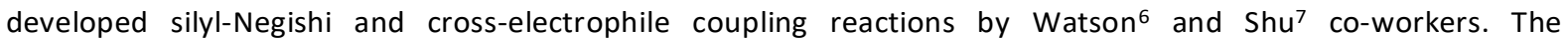
complementary silyl anions are also well established, and silylzinc reagents in general are one of the most appealing 8 owing to their excellent functional group tolerance. Earlier in 1984, Oshima et al. described the synthesis of silylzinc reagents, ${ }^{9}$ and Oestreich and co-workers followed up with elegant applications. ${ }^{10}$

However, it is notoriously difficult to synthesis silylzinc reagents because it requires the preparation of silyllithium reagents. ${ }^{11}$ In particular, preparation of $\mathrm{Me}_{3} \mathrm{SiLi}$ necessitates treating MeLi with hexamethyldisilane in HMPA, evidencing the remarkably high activation barrier required for effecting $\mathrm{Si}-\mathrm{X}$ cleavage. Furthermore, the application of these reagents may be limited due to dissolved lithium halides. The direct synthesis of silylzinc reagents is undoubtedly the desirable and economic route for the synthesis of silylzinc reagents, as it avoids the handling of pyrophoric silyllithium. Additional benefits may be obtained if the reagents are accessible as solids. Despite considerable advances have been made in the preparation of organozinc reagents, particularly by following 
Knochel's protocols, ${ }^{12}$ the existing methods are not amenable to the synthesis of silylzinc reagents through oxidative addition of zinc to silyl halides.

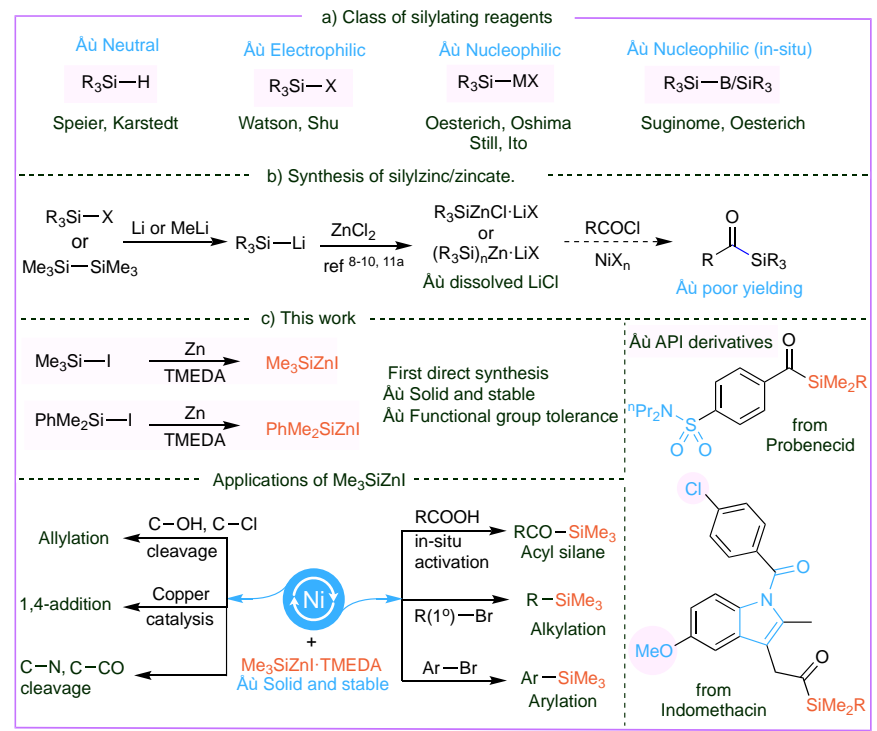

Figure 1. Synthesis of silylzinc reagents and acylsilanes.

Acylsilanes, on the other hand, are versatile and unique building blocks in organic synthesis. ${ }^{13}$ They undergo a broad range of reactions including nucleophilic addition, ${ }^{14}$ transition-metal mediated reactions ${ }^{15}$ and intriguing transformations. ${ }^{16}$ Importantly they have been utilized as acyl anion synthetic equivalent via Brook rearrangement. ${ }^{13 \mathrm{~d}, 13 \mathrm{f}, 14 \mathrm{~d}, 15 \mathrm{a}, 17}$ It is ideal to employ carboxylic acid derivatives to synthesize acylsilanes, indeed stoichiometric organosilicon reagents ${ }^{18}$ or disilanes ${ }^{19}$ or stannylsilanes ${ }^{20}$ in presence of catalytic palladium at 110 ${ }^{\circ} \mathrm{C}$ were deployed to synthesize acylsilanes. Despite the initial achievements, the synthesis of acylsilanes still involve a tedious protocol, as seen by contemporary literature that uses the classical multistep 1,3-dithiane protocol, ${ }^{21}$ or inconvenient protocols. ${ }^{16 a}$ Our attempts to couple silylzinc (prepared from silyllithium) and acid chlorides yielded poor results, perhaps owing to the dissolved LiCl, emphasizing the need for a new and facile synthetic strategy.

Herein we describe the first direct preparation of silylzinc reagents from silyl iodides and subsequent cross-coupling reactions with free carboxylic acids to generate a library of acylsilanes with broad functional group tolerance. In addition, the newly developed solid $\mathrm{Me}_{3} \mathrm{SiZnI}$ was successfully employed in a broad range of organic transformations including alkylation, arylation, allylation, 1,4-addition, acylation, cross-coupling via $\mathrm{C}-\mathrm{N}$ bond cleavage, Brook rearrangement and decarboxylation.

\section{Results and Discussion}

Table 1: Synthesis of silylzinc reagents ${ }^{a}$

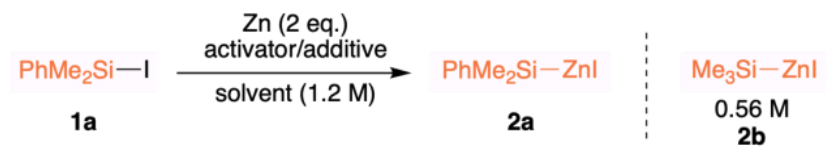

\begin{tabular}{|l|l|l|l|}
\hline entry & activator & \multicolumn{1}{|c|}{ additive, solvent, temperature } & 2a(M) \\
\hline 1 & - & $\mathrm{THF}, 60^{\circ} \mathrm{C}$ & $\mathrm{ND}$ \\
2 & $\mathrm{TMSCl}$ & $\mathrm{THF}, 60^{\circ} \mathrm{C} /$ toluene, $70^{\circ} \mathrm{C}$ & $\mathrm{ND}$ \\
3 & iodine & $\mathrm{DMA}, 80^{\circ} \mathrm{C} /$ toluene, $70^{\circ} \mathrm{C}$ & $\mathrm{ND}$ \\
4 & - & $\mathrm{LiCl}$, toluene, $70^{\circ} \mathrm{C}$ & $\mathrm{ND}$ \\
5 & $\mathrm{DBE}$ & $\mathrm{LiCl}$, toluene, $70^{\circ} \mathrm{C} / \mathrm{THF}, 60^{\circ} \mathrm{C}$ & $\mathrm{ND}$ \\
6 & iodine & $\mathrm{TMEDA}$, toluene, $66^{\circ} \mathrm{C}, 63 \mathrm{~h}$ & 0.21 \\
7 & iodine & $\mathrm{TMEDA}$, toluene, $70-90^{\circ} \mathrm{C}, 63 \mathrm{~h}$ & $0.68^{\mathrm{c}}$ \\
8 & iodine & $\mathrm{NMP} / \mathrm{DMA}$, toluene, $85^{\circ} \mathrm{C}$ & $\mathrm{ND}$ \\
\hline
\end{tabular}


aReaction condition: additive/activator: $\mathrm{Me}_{3} \mathrm{Si}-\mathrm{Cl}$ (0.12 eq.), iodine (0.03/0.05 eq.), DBE (0.03 eq.), LiCl (1.0 eq.), TMEDA (1.1 eq.), NMP/DMA (1.5 eq.). ${ }^{b} \mathrm{Me}_{3} \mathrm{SiCl}$ (1.5 mol\%) was used. can average of 5 isolated runs. M: Molarity, DBE: 1,2dibromoethane, NMP: N-Methyl-2-pyrrolidone, DMA: Dimethylacetamide, ND: not detected.

We began our studies with silyl iodide 1a which was prepared from the corresponding $\mathrm{PhMe}_{2} \mathrm{SiH}^{6,22} \mathrm{It}$ has been reported in the literature that the activation of zinc is crucial and there are multiple methods known for the activation of zinc ${ }^{23}$ including $\mathrm{HCl}$ wash, ${ }^{24} \mathrm{Me}_{3} \mathrm{SiCl},{ }^{25}$ iodine, ${ }^{26}$ ultrasound ${ }^{27}$ and dibromoethane activation. ${ }^{28}$ We have also followed these protocols for the activation of zinc and subjected them in the oxidative addition to silyl iodide $1 \mathbf{a}$, the results are summarized in table 1 . As expected, no silylation was observed in the absence of an activator or additive (entry 1). Initially, activation was carried out with $\mathrm{Me}_{3} \mathrm{SiCl}$ (entries 2 and 5), later iodine (entries 3 and 6-8) and DBE (entry 5) were employed to activate Zn. In general, THF was not suitable (entries 1, 2, and 5), the $\mathrm{C}-\mathrm{O}$ bond in THF was cleaved under the reflux condition (figure 1 in $\mathrm{SI}, \mathrm{S} 5-\mathrm{S} 7$ ), a similar observation was reported during the synthesis of silylmagnesium reagents. ${ }^{29}$ The group of Knochel extensively studied the role of $\mathrm{LiCl}$ in the preparation of organometallic reagents including organozinc reagents. ${ }^{12}$ The same group reported the combination of $\mathrm{LiCl}$, dibromoethane and $\mathrm{Me}_{3} \mathrm{SiCl}$ which is highly efficient for the preparation of alkyl zinc reagents. ${ }^{12 \mathrm{e}}$ Unfortunately, the inclusion of $\mathrm{LiCl}$ as an additive or DBE as an activator was inconsequential (entries 4 and 5).

In the backdrop of our recent finding on the preparation of $\mathrm{Me}_{3} \mathrm{SiMgl}$ from $\mathrm{Me}_{3} \mathrm{Sil}^{29-30}$ and the literature finding of polar solvents such as dimethylacetamide 26,31 , hexamethylphosphoramide, ${ }^{32} \mathrm{~N}, \mathrm{~N}$-dimethylformamide ${ }^{26-27,31}$, dimethylsulfoxide, ${ }^{32}$ acetonitrile, ${ }^{33}$ tetramethylurea, ${ }^{27 a} \mathrm{CH}_{3} \mathrm{CN}-$ Pyridine $^{33}$ and N-Methyl-2-pyrrolidone (NMP27a) favoring the generation of organozinc reagents, we envisioned amine additives may assist the formation of silylzinc reagents. Pleasingly, we observed a successful oxidative addition of zinc in an industrial friendly solvent ${ }^{34}$ toluene along with 1.1 eq. of TMEDA was employed as an additive (entry 6). An increase in the reaction temperature also increased the concentration of PhMe ${ }_{2} \operatorname{SiZnl}$ (entry 6 vs 7). As shown in entry 8 , no reactivity was observed with either NMP or DMA as additives. The methodology is not limited to the synthesis of $\mathrm{PhMe}_{2} \mathrm{SiZnl} 2 \mathrm{a}$, even the relatively less reactive $\mathrm{Me}_{3} \mathrm{Sil}$ was successfully employed to generate more productive $\mathrm{Me}_{3} \mathrm{SiZnl} \mathbf{2 b}$ with $0.56 \mathrm{M}$ (average of 4 runs) concentration. Moreover, these silylzinc reagents stored at $4{ }^{\circ} \mathrm{C}$ did not decompose even after six months. Importantly, we obtained structures of PhMe ${ }_{2} \mathrm{SiZnl} \cdot \mathrm{TMEDA}$ and $\mathrm{Me}_{3} \mathrm{SiZnI} \cdot \mathrm{TMEDA}$ from single crystal XRD for the first time (figure 2). It is apparent from these structures that TMEDA stabilizes $\mathbf{2 a}$ and $\mathbf{2 b}$, driving force for the oxidative addition.

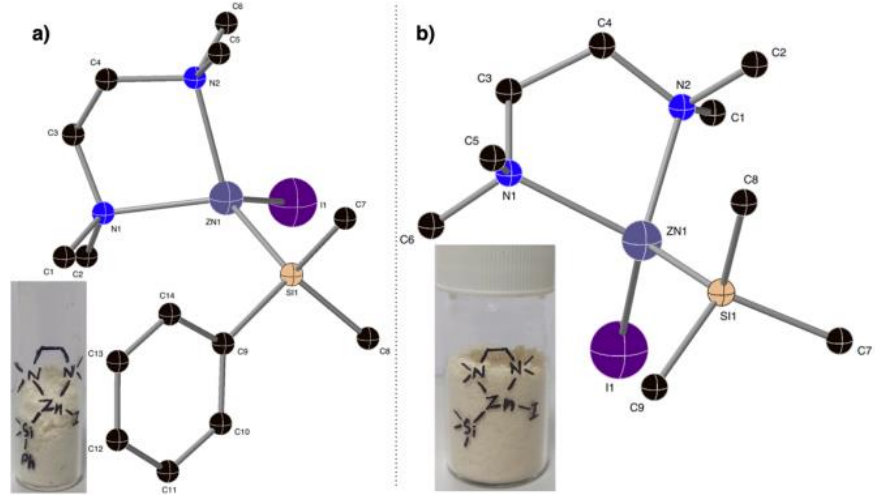

Figure 2. X-ray crystal structures of (a) PhMe 2 SiZnI-TMEDA and (b) $\mathrm{Me}_{3} \mathrm{SiZnI} \cdot \mathrm{TMEDA}$ complex, the hydrogen atoms have been omitted for clarity.

At the outset of our studies, we screened a range of nickel catalysts to obtain the acylsilane $\mathbf{5 a}$ (see $\mathrm{SI}-10$ for complete table). The initial experiments were carried out with the isolated acid chloride 4a derived from 3-(4-methoxyphenyl)propanoic acid 3a, however, the later experiments (entries 8-16, 20) were carried out with free carboxylic acid 3a via in-situ generation of acid chloride $4 \mathrm{a}$. When $10 \mathrm{~mol} \%$ of $\mathrm{NiBr}_{2}$. diglyme was employed, we observed $60 \%$ of the cross-coupling product 5 a (entry 1 , table 1). The yield of $\mathbf{5 a}$ was greatly improved by increasing the reaction temperature from $45^{\circ} \mathrm{C}$ to $60^{\circ} \mathrm{C}$ (entry 1 vs 2 ). It is important to note that the activation of $\mathrm{NiBr}_{2}$-diglyme $\left(10 \mathrm{~mol} \%\right.$ ) requires $20 \mathrm{~mol} \%$ of $\mathrm{PhMe}_{2} \mathrm{SiZnl}$. The other nickel catalysts including $\mathrm{NiCl}_{2}, \mathrm{Ni}(\mathrm{acac})_{2}$ and $\mathrm{NiBr}_{2}$ bpy afforded $\mathbf{5 a}$ in only $29 \%, 66 \%$ and $21 \%$ yields, with the hydrolyzed acid $3 a$ being formed as the major byproduct (entries 3-5). To our surprise, the hydrated and air stable $\mathrm{Ni}(\mathrm{OAc})_{2} \cdot 4 \mathrm{H}_{2} \mathrm{O}$ afforded the cross-coupled product $\mathbf{5 a}$ in $\mathbf{8 6 \%}$ yield (entry 6). A library of ligands was also screened, a simple bipyridine led to a significant reduction in the yield (entry 8), TMEDA and dppe were poor yielding (entries 9-10). The non-polar toluene was not compatible (entry 11). A remarkable improvement in yield to $95 \%$ was obtained in DME (entry 12), although the dielectric constant (polarity) and coordinating ability of DME does not significantly vary from that of THF.

Table 2. Optimization. ${ }^{\text {a }}$

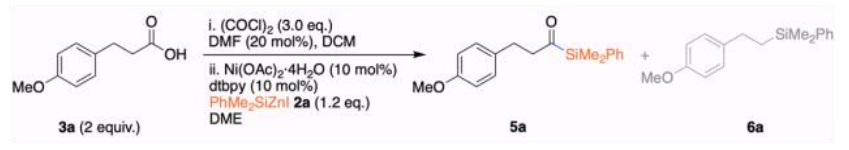




\begin{tabular}{|c|c|c|c|}
\hline entry & deviation from above & temp., time & $5 a(\%)^{b}$ \\
\hline 1 & $\mathrm{NiBr}_{2} \cdot$ diglyme, $\mathrm{THF}$ & $45^{\circ} \mathrm{C}, 4 \mathrm{~h}$ & $60^{c}$ \\
\hline 2 & $\mathrm{NiBr}_{2} \cdot$ diglyme, THF & $60^{\circ} \mathrm{C}, 4 \mathrm{~h}$ & 92 \\
\hline 3 & $\mathrm{NiCl}_{2}, \mathrm{THF}$ & $60^{\circ} \mathrm{C}, 4 \mathrm{~h}$ & $29^{d}$ \\
\hline 4 & $\mathrm{Ni}(\mathrm{acac})_{2}, \mathrm{THF}$ & $60^{\circ} \mathrm{C}, 4 \mathrm{~h}$ & 66 \\
\hline 5 & $\mathrm{NiBr}_{2} \mathrm{bpy}$, THF & $60^{\circ} \mathrm{C}, 4 \mathrm{~h}$ & 21 \\
\hline 6 & THF & $60^{\circ} \mathrm{C}, 4 \mathrm{~h}$ & 86 \\
\hline 7 & $20 \mathrm{~mol} \%$ of $\mathrm{Cul}$ or $\mathrm{CuCN}$ & $60^{\circ} \mathrm{C}, 4 \mathrm{~h}$ & 2 \\
\hline 8 & bpy instead dtbpy, THF & $60^{\circ} \mathrm{C}, 4 \mathrm{~h}$ & $70^{d}$ \\
\hline 9 & TMEDA instead dtbpy, THF & $60^{\circ} \mathrm{C}, 4 \mathrm{~h}$ & $28^{d}$ \\
\hline 10 & dppe instead dtbpy, THF & $60^{\circ} \mathrm{C}, 4 \mathrm{~h}$ & 10 \\
\hline 11 & toluene & $60^{\circ} \mathrm{C}, 4 \mathrm{~h}$ & 38 \\
\hline 12 & none & $60^{\circ} \mathrm{C}, 4 \mathrm{~h}$ & 95 \\
\hline 13 & none & $\mathrm{rt}, 12 \mathrm{~h}$ & 90 \\
\hline 14 & $5 \mathrm{~mol} \% \mathrm{Ni}(\mathrm{OAc})_{2} \cdot 4 \mathrm{H}_{2} \mathrm{O}$ & $\mathrm{rt}, 12 \mathrm{~h}$ & $94(86)^{f}$ \\
\hline 15 & $2 \mathrm{~mol} \% \mathrm{Ni}(\mathrm{OAc})_{2} \cdot 4 \mathrm{H}_{2} \mathrm{O}$ & $\mathrm{rt}, 12 \mathrm{~h}$ & 52 \\
\hline 16 & $\mathrm{Ni}(C O D)_{2}$ (1.5 eq. $\left.3 a\right)$, THF & $\mathrm{rt}, 12 \mathrm{~h}$ & 95 \\
\hline 17 & without $\mathrm{Ni}(\mathrm{OAc})_{2} \cdot 4 \mathrm{H}_{2} \mathrm{O}$ & $\mathrm{rt}, 12 \mathrm{~h}$ & 2 \\
\hline 18 & silylzinc from $\mathrm{PhMe}_{2} \mathrm{SiLi}$ & $\mathrm{rt}, 12 \mathrm{~h}$ & 23 \\
\hline 19 & 1 eq. $\mathrm{LiCl}$ additive & $\mathrm{rt}, 12 \mathrm{~h}$ & 42 \\
\hline 20 & $4.2 \mathrm{mmol}$ of $2 \mathrm{a}$ & $\mathrm{rt}, 12 \mathrm{~h}$ & (80) \\
\hline
\end{tabular}

aReaction condition: $0.39 \mathrm{mmol}$ of $3 \mathrm{a}, 0.234 \mathrm{mmol}$ of PhMe $2 \mathrm{SiZnl} \cdot$ TMEDA 2a (0.66 M in toluene), $0.0195 \mathrm{mmol}$ of $\mathrm{Ni}(\mathrm{OAc})_{2} \cdot 4 \mathrm{H}_{2} \mathrm{O}$ and dtbpy, $0.17 \mathrm{M}$ (overall concentration). Isolated acid-chloride 4 a was used in entries 1-7 and 17-19, in-situ acid-chloride 4 a was used in entries 8-16 and 20. bYield determined by ${ }^{1} \mathrm{H}$ NMR using 1,3,5-trimethoxy benzene as an internal standard. ${ }^{\mathrm{c}} 1.3 \mathrm{eq}$. of $\mathrm{PhMe}_{2} \mathrm{SiZnl}$. d Incomplete reaction, unreacted starting material was observed in the crude NMR. e1.0 eq. of $\mathrm{PhMe}_{2} \mathrm{SiZnl}$ was used. ${ }^{\mathrm{f}}$ Reactions were repeated at least 10 times throughout the project. DME: 1,2-dimethoxy ethane, yield in parenthesis is isolated yield.

Pleasingly, the reaction can be performed at room temperature without a compromise in the yield (entry 13). Interestingly, $5 \mathrm{~mol} \%$ of $\mathrm{Ni}(\mathrm{OAc})_{2} \cdot 4 \mathrm{H}_{2} \mathrm{O}$ afforded the cross-coupled $\mathbf{5 a}$ in $86 \%$ isolated yield (entry 14). A further decrease in the loading of catalyst ( 2 mol\%) decreased the yield of $5 a$ (entry 15). When $\mathrm{Ni}(\mathrm{COD})_{2}$ was employed as a catalyst, 1.5 eq. of carboxylic acid 3a was sufficient to obtain excellent yield (entry 16). Virtually no cross-coupled product 5a was observed in the absence of $\mathrm{Ni}(\mathrm{OAc})_{2} \cdot 4 \mathrm{H}_{2} \mathrm{O}$ (entry 17). Notably, $\left(\mathrm{PhMe}_{2} \mathrm{Si}\right)_{2} \mathrm{Zn}^{8 \mathrm{a}, 8 \mathrm{~h}}$ and $\mathrm{PhMe}_{2} \mathrm{SiZnCl}{ }^{8 j}$ reagents prepared from silyllithium were found to be incompatible and the product $5 \mathrm{a}$ was observed in only $23 \%$ yield (entry 18 ), the dissolved LiCl may be at play. The detrimental effect of $\mathrm{LiCl}$ was confirmed by the addition of $1 \mathrm{eq}$. of $\mathrm{LiCl}$ to the standard reaction that significantly reduced the yield (entry 19). To expand the synthetic utility, we also conducted the reaction on a $4.2 \mathrm{mmol}$ scale using $5 \mathrm{~mol} \%$ of $\mathrm{Ni}(\mathrm{OAc})_{2} \cdot 4 \mathrm{H}_{2} \mathrm{O}$ and obtained $\mathbf{5 a}$ in $80 \%$ isolated yield (entry 20 ). We also found that the mode of addition is critical to obtain a consistent result; $\mathrm{PhMe}_{2} \mathrm{SiZnl}$ must be added drop wise at the end of sequential addition, change in the sequence resulted in a significant loss in the yield.

Table 3. Cross-coupling with $\mathrm{PhMe}_{2} \mathrm{SiZnI}^{\mathrm{a}}$ 


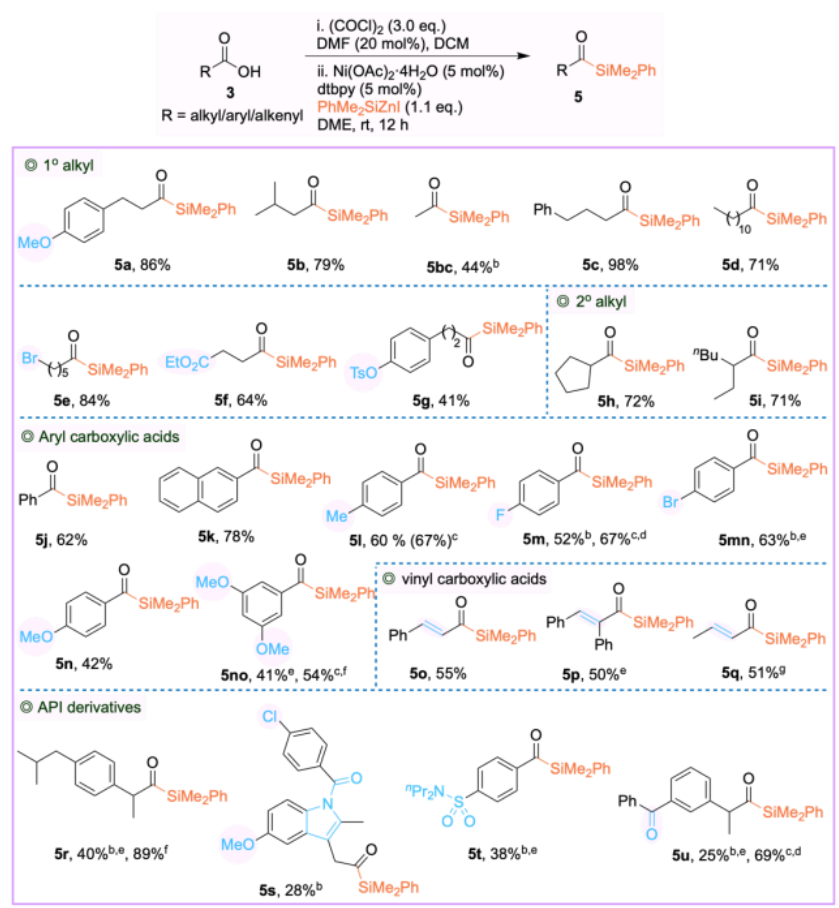

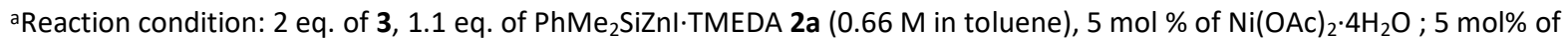
dtbpy, 1,2-dimethoxy ethane (0.17 M). ${ }^{b}$ unreactive PhMe ${ }_{2} \mathrm{SiZnI} \cdot \mathrm{TMEDA}$ was observed as $\mathrm{PhMe}_{2} \mathrm{SiH}$. ${ }^{\mathrm{C} N M R}$ yield. ${ }^{\mathrm{d} C o n d i t i o n:}$ 2 eq. of 3, 1 eq of $\mathrm{PhMe}_{2} \mathrm{SiZnl} \cdot \mathrm{TMEDA}$ ( $0.71 \mathrm{M}$ in toluene), $20 \mathrm{~mol} \%$ of Cul, 1 eq. of LiCl, 1,2-dimethoxy ethane ( $0.15 \mathrm{M}$ overall concentration), $0{ }^{\circ} \mathrm{C}$ - rt. edecarbonylative byproduct was observed. ${ }^{\mathrm{f}} 10 \mathrm{~mol} \% \mathrm{Ni}(\mathrm{OAc})_{2} \cdot 4 \mathrm{H}_{2} \mathrm{O}, 10 \mathrm{~mol} \%$ 1,10-phen, $20 \mathrm{~mol} \%$ of Cul was added. sBrook rearrangement was observed.

Having identified the optimal reaction condition (Table 2, Entry 14), we proceeded to examine the scope of carboxylic acids. The primary alkyl carboxylic acids $\mathbf{3 a - 3 g}$ including the long chain alkyl carboxylic acid afforded the cross-coupled products $\mathbf{5 a}-\mathbf{5 g}$ in good to excellent yields. The $\alpha$-branched secondary alkyl carboxylic acids $\mathbf{3 h}$ - $\mathbf{3 i}$ had no impact on the efficiencies and afforded the corresponding acylsilanes $\mathbf{5 h}-\mathbf{5 i}$ in very good yields. Aryl carboxylic acids $\mathbf{3} \mathbf{j}$-3no including $\pi$-extended naphthalene-2-carboxylic acid 3k and alkenyl carboxylic acids 3o-3q were also compatible affording the corresponding acylsilane in good yields. The moderate yield concerning $5 \mathbf{b c}, 5 \mathrm{~m}, 5 \mathrm{mn}$ and $\mathbf{5 r}-\mathbf{5 u}$ can be attributed to the incomplete reaction as we observed a significant amount of $\mathrm{PhMe}_{2} \mathrm{SiH}$ at the end of reaction. We have also observed traces of decarbonylated byproduct during the synthesis of acylsilanes $\mathbf{5 m n}, \mathbf{5 n o}, \mathbf{5 p}, \mathbf{5 r}$ and $\mathbf{5 t}-\mathbf{5 u}$. Various functional groups such as ethers (3a, 3n, 3no, and 3s), alkyl/aryl bromides (3e and $\mathbf{3 m n}$ ), chloride $\mathbf{3 s}$ and medicinally relevant fluoride $\mathbf{3 m}$ were tolerated, affording the corresponding cross-coupled products in good to high yields. Carbonyls did not impede the reactivity of silylzinc reagents, ester $\mathbf{3 f}$, ketone $\mathbf{3 u}$ and amide $\mathbf{3 s}$ were compatible, despite their moderate yielding. The O-tosyl protecting group $\mathbf{3 g}$ was also compatible. The structurally complex API substances did not impede the reaction, indomethacin $\mathbf{3 s}$, probenecid $\mathbf{3 t}$, anti-inflammatory drug ibuprofen $\mathbf{3 r}$, and ketoprofen $\mathbf{3 u}$ afforded the corresponding silylated products $\mathbf{5 r}-\mathbf{5 u}$. As we observed lower yields on a few substrates, we needed to design a complementary copper catalysis to obtain an increased yield. In place of $\mathrm{Ni}(\mathrm{OAC})_{2} \cdot 4 \mathrm{H}_{2} \mathrm{O}$, we employed catalytic Cul along with $\mathrm{LiCl}$ additive, which resulted in higher yields for substrates $5 \mathrm{~m}$ and $\mathbf{5 u}$. For substrate $\mathbf{5 r}$, a dual system incorporating both $\mathrm{Ni}\left(\mathrm{OAc}_{2} \cdot 4 \mathrm{H}_{2} \mathrm{O}\right.$ and Cul resulted in a significant increase in yield ( $40 \%$ vs $89 \%)$.

Table 4. Cross-coupling with $\mathrm{Me}_{3} \mathrm{SiZnl}{ }^{\mathrm{a}}$ 


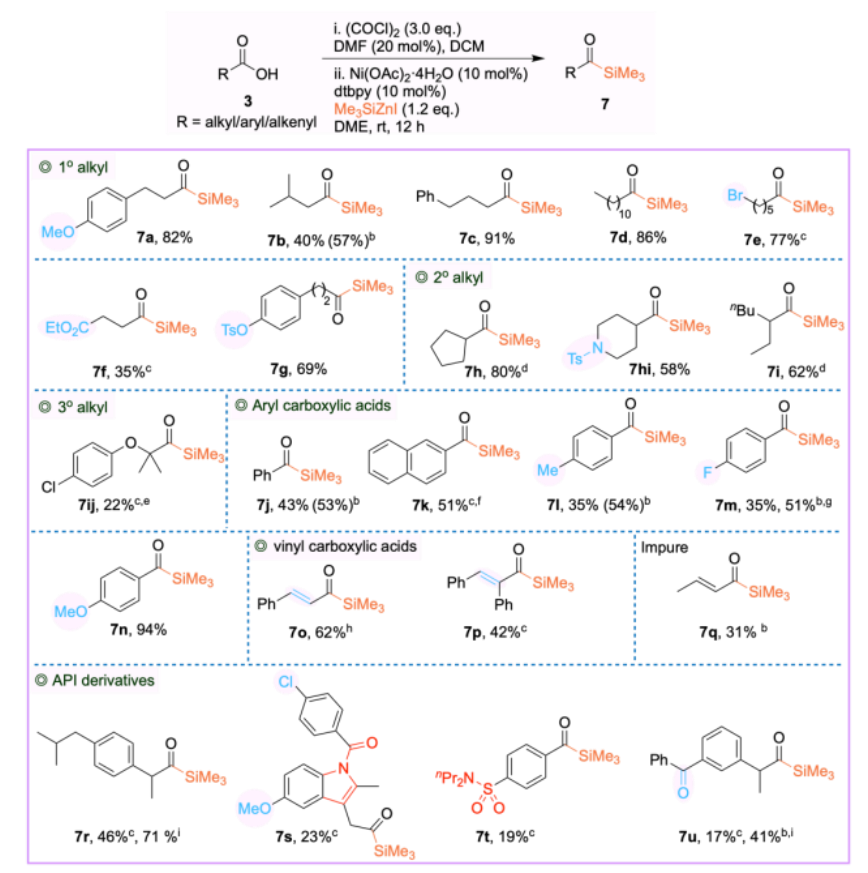

a2 eq. of 3; 1.2 eq. of $\mathrm{Me}_{3} \mathrm{SiZnl} \cdot \mathrm{TMEDA} 2 \mathrm{~b}(0.56 \mathrm{M}$ in toluene, $1.19 \mathrm{mmol}) ; 10 \mathrm{~mol} \% \mathrm{Ni}(\mathrm{OAc})_{2} \cdot 4 \mathrm{H}_{2} \mathrm{O} ; 10 \mathrm{~mol} \% \mathrm{dtbpy}, 1,2-$ dimethoxy ethane $(0.17 \mathrm{M})$. ${ }^{b} \mathrm{NMR}$ yield. ${ }^{\mathrm{c}}$ decarbonylative byproduct was observed. dimerization of $\mathbf{3}$ to diketone was observed. e $\mathrm{Ni}(\mathrm{COD})_{2}(10 \mathrm{~mol} \%)$ instead of $\mathrm{Ni}(\mathrm{OAc})_{2} \cdot 4 \mathrm{H}_{2} \mathrm{O}$. ${ }^{f}$ decomposition on silica was observed. ${ }^{8}$ Condition: 2 eq. of 3, 1eq of $\mathrm{PhMe}_{2} \mathrm{SiZnI} \cdot \mathrm{TMEDA}(0.71 \mathrm{M}$ in toluene), $20 \mathrm{~mol} \%$ of $\mathrm{Cul}, 1$ eq. of $\mathrm{LiCl}, 1,2$-dimethoxy ethane $(0.15 \mathrm{M}$ overall concentration), $0{ }^{\circ} \mathrm{C}-\mathrm{rt}$. ${ }^{\mathrm{h}} 6 \mathrm{mmol}$ of $\mathbf{2} \mathbf{b}$ was employed. ${ }^{1} 10 \mathrm{~mol} \% \mathrm{Ni}(\mathrm{OAc})_{2} \cdot 4 \mathrm{H}_{2} \mathrm{O}, 10 \mathrm{~mol} \%$ 1,10-phen, $20 \mathrm{~mol} \%$ of Cul was added.

Importantly, the reaction is also compatible with $\mathrm{Me}_{3} \mathrm{SiZnl} \mathbf{2} \mathbf{b}$, affording the widely used TMS derived acylsilanes $\mathbf{7}$ in good to excellent yields. It was necessary to increase the loading of the catalyst to $10 \mathrm{~mol} \%$ to improve the yield. Similar to $\mathrm{PhMe}_{2} \mathrm{SiZnl} \mathbf{2 a}, \mathrm{Me}_{3} \mathrm{SiZnl} \mathbf{2} \mathbf{b}$ was also an efficient reagent (Table 4), primary and secondary alkyl carboxylic acids 3a-3i with various functional groups afforded the cross-coupled products $\mathbf{7 a - 7 i}$ in good to excellent yields. Aryl and vinyl carboxylic

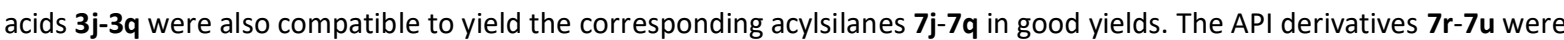
also silylated albeit in lower to moderate yields. In addition, the sterically hindered tertiary alkyl carboxylic acid $3 \mathbf{i j}$ afforded acylsilane $\mathbf{7 i j}$ in lower yield, an incomplete reaction and decarbonylative protonation may account for the lower yield. Both $\mathrm{Ni}(\mathrm{OAc})_{2} \cdot 4 \mathrm{H}_{2} \mathrm{O}$ and $\mathrm{Ni}(\mathrm{COD})_{2}$ afforded the acylsilane $7 \mathrm{ij}$ in similar yields. $\mathrm{N}$-tosyl protected isonipecotic acid $3 \mathrm{hi}$ was compatible affording the acylsilane $\mathbf{7 h i}$ in $58 \%$ isolated yield. In general, aryl carboxylic acids gave traces of decarbonylated products and increasing the reaction temperature further increased the undesired decarbonylative silylation. It is worth noting that the decarbonylation can generate catalytically inactive $\mathrm{L}_{n} \mathrm{Ni}(\mathrm{CO})_{x}$ species. ${ }^{35}$ Additionally, copper catalysis was employed to improve the yield of product $7 \mathrm{~m}$. Importantly, the dual $\mathrm{Ni}(\mathrm{OAc})_{2} / \mathrm{Cul}$ catalytic system significantly improved the yields for substrates $7 \mathbf{r}$ and $\mathbf{7 u}$. Gram-scale synthesis of acylsilanes $\mathbf{5 e}(3.5 \mathrm{mmol}), 7 \mathbf{7}(5 \mathrm{mmol})$, and 7 e $(4 \mathrm{mmol})$ were promising with $82 \%, 70 \%$ and $76 \%$ isolated yields.

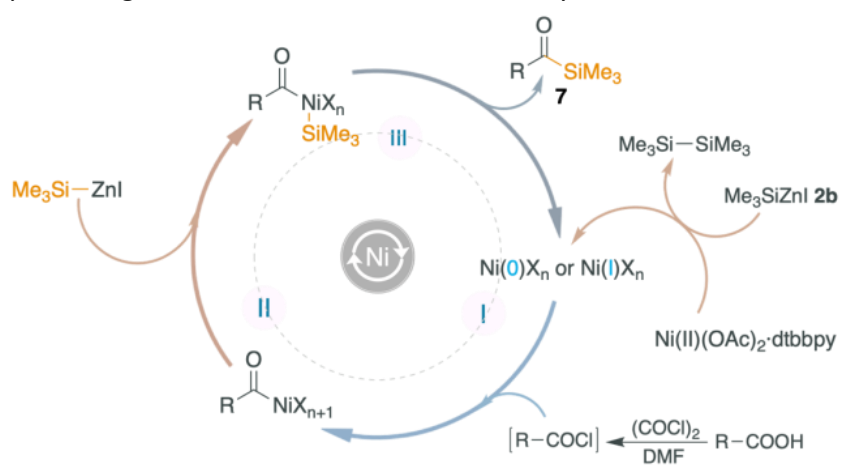

Figure 3. Mechanistic hypothesis.

A hypothetical mechanism is shown in figure 3 . When $\mathrm{Ni}(\mathrm{OAc})_{2}$ was exposed to $\mathrm{Me}_{3} \mathrm{SiZnl}$ or $\mathrm{PhMe}_{2} \mathrm{SiZnl}$, we observed the formation of disilane with the concomitant formation of a low valent nickel complex $\mathbf{I}$. It has been reported in the literature that the use of organozinc reagents in cross-coupling reactions can lead to either $\mathrm{Ni}(0)^{12 b, 36}$ or $\mathrm{Ni}(\mathrm{I})^{37}$ intermediacy complexes. The low valent nickel complex I undergoes oxidative addition with in-situ generated acid chloride to generate 
the intermediate complex II. Subsequent transmetallation to intermediate III and reductive elimination affords the acylated product $\mathbf{5}$ or $\mathbf{7}$ while regenerating the active catalyst $\mathrm{I}$.

In table $2-4$, the silylzinc reagents $\mathbf{2 a}$ and $\mathbf{2} \mathbf{b}$ were employed as $0.68 \mathrm{M}$ and $0.56 \mathrm{M}$ solutions respectively. While studying the stability of these reagents, we discovered that they are quite stable in the form of solid. In order to study the general applicability of these new solid $\mathrm{Me}_{3} \mathrm{SiZnI} \mathbf{2} \mathbf{b}$, we performed a wide range organic transformations and the results are summarized in figure 4 . Initially, both branched and linear allylsilanes $\mathbf{8 b}$ and $\mathbf{9 b}$ were synthesized through allylation. In the presence of catalytic $\mathrm{CuCN}$, allyl chloride $\mathbf{8 a}$ was treated with $\mathbf{2} \mathbf{b}$ to generate the branched allylated product $\mathbf{8 b}$ in $\mathbf{7 3 \%}$ isolated yield. ${ }^{88,38}$ Using allylic alcohol $9 a$ in the presence of nickel catalyst, the linear silane $9 \mathbf{b}$ was likewise produced in $69 \%$ yield as a single isomer. ${ }^{8 d, 39}$ Because aryl silanes are commonly used in synthetic applications, ${ }^{40}$ we employed $\mathbf{2} \mathbf{b}$ in a nickelmediated cross-coupling process of aryl bromide 10a, which resulted in the synthesis of aryl silane $10 \mathrm{~b}$ in $70 \%$ isolated yield. ${ }^{41}$ Cross-coupling of $2^{\circ}$-alkyl bromide and $\mathrm{PhMe}_{2} \mathrm{SiZnCl}$ was recently realized, ${ }^{8 \mathrm{e}}$ and we were ecstatic to see that the new reagent $\mathbf{2} \mathbf{b}$ was effective in undergoing the cross-coupling reaction with $1^{\circ}$-alkyl bromide $11 \mathbf{a}$, yielding the alkyl silane $\mathbf{1 1} \mathbf{b}$ in a $\mathbf{7 1 \%}$ isolated yield. Fortunately, the copper-mediated 1,4 -addition of $\mathbf{2} \mathbf{a}$ and $\mathbf{2} \mathbf{b}$ with enones $\mathbf{1 2} \mathbf{a}$ and $\mathbf{1 3 a}$ yielded the $\beta$-silyl ketones $\mathbf{1 2} \mathbf{b}$ and $\mathbf{1 3} \mathbf{b}$ in $\mathbf{7 3 \%}$ and $\mathbf{7 1 \%}$ isolated yields, respectively. ${ }^{8 h, 42}$ Acylsilane $\mathbf{5} \mathbf{j}$ was also synthesized by coupling of acid chloride $\mathbf{3} \mathbf{j}$ and $\mathbf{2} \mathbf{a}$ in the presence of $\mathbf{C u C l}$. We also employed $\mathbf{2 a}$ in a novel Brook-rearrangement/crosscoupling of benzaldehyde and bromoarene, ${ }^{43}$ however, $\mathbf{1 4 b}$ was observed in poor yield. A similar result was obtained in a multi component reaction between, styrene, acid chloride and $\mathbf{2} \mathbf{b}$ to yield product $\mathbf{1 5 b}{ }^{44}$ Pyridinium salt $\mathbf{1 6 a}$ and redox ester $\mathbf{1 7 a}$ underwent cross-coupling reactions with $\mathbf{2} \mathbf{b}$ to afford alkyl silanes $\mathbf{1 6} \mathbf{b}$ and $\mathbf{1 7 b}$ in only $\mathbf{2 0 \%}$ and $10 \%$ isolated yields respectively, indicating the need for dedicated studies. Samples of solid $\mathbf{M e}_{3} \mathrm{SiZnl} \mathbf{2} \mathbf{b}$ were stored at three different temperatures $\left(\mathrm{rt}, 4^{\circ} \mathrm{C}\right.$ and $-23^{\circ} \mathrm{C}$ ) for the period of two months and subjected in the cross-coupling of 10a to afford the aryl silane $\mathbf{1 0 b}$. The silylzinc $\mathbf{2 b}$ stored at $4{ }^{\circ} \mathrm{C}$ and $-23^{\circ} \mathrm{C}$ was equally effective as the freshly prepared reagent, however, $\mathrm{Me}_{3} \mathrm{SiZnl}$ (two different batches) stored at room temperature gave poor yield (SI-S51).

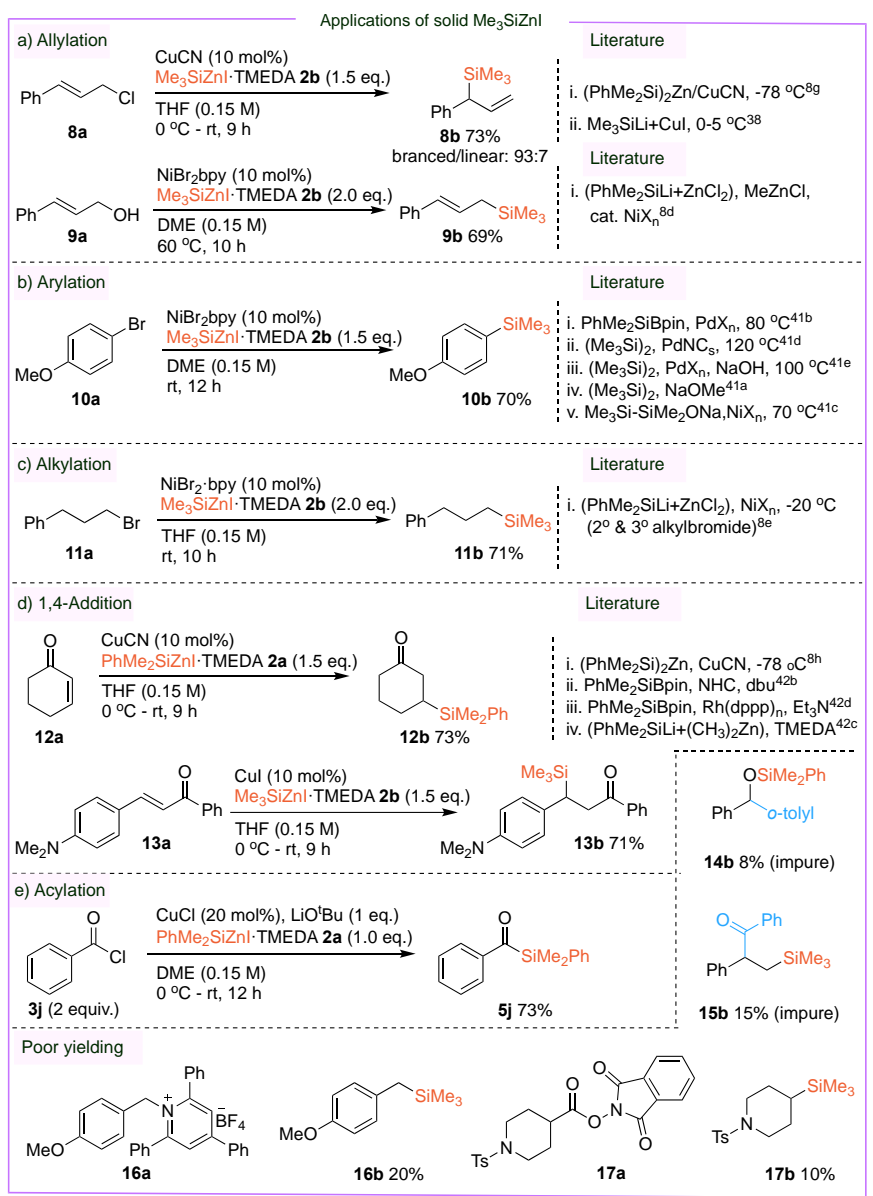

Figure 4. Synthetic application of solid $\mathrm{Me}_{3} \mathrm{SiZnl}$.

\section{Conclusions}

In summary, for the first time, we have developed a method for direct synthesis of silylzinc reagents from silyl iodides and their structures were confirmed by single crystal XRD. Unlike the use of 
pyrophoric silyllithium in the synthesis of silylzinc reagents, the current method offers a simplified direct method to access them from silyl halides. The absence of dissolved lithium/magnesium salts in these reagents could be beneficial for various chemical processes. We have also demonstrated the practical synthesis of acylsilanes from unactivated alkyl carboxylic acids by nickel, copper and dual catalysis. The methodology is compatible with various functional groups, accommodates sterically hindered secondary and tertiary alkyl carboxylic acids. Structurally complex and API molecules are also silylated conveniently. The general synthetic utility of these reagents is shown in a broad range of reactions. Further study to expand the synthetic scope of these reagents is currently underway in our laboratory.

\section{Author Contributions}

The manuscript was written through contributions of all authors. R.C, F.T.P and K.S performed the experiments. All authors have approved the final version of the manuscript.

\section{Conflicts of interest}

The authors declare no competing financial interest.

\section{Acknowledgements}

We thank the Science and Engineering Research Board, Ramanujan Fellowship SB/S2/RJN059/2015, CSIR (Council of Scientific and Industrial Research) 02(0409)/21/EMR-II and IISER Trivandrum for financial support. RC acknowledges CSIR, FTP acknowledges IISER Trivandrum and KS acknowledges DST-inspire for fellowships.

\section{Notes and references}

1 (a) A. Franz and S. Wilson, J. Med. Chem., 2013, 56, 388; (b) P. L. Fuchs, Handbook of reagents for organic synthesis, reagents for siliconmediated organic synthesis, John Wiley \& Sons, 2011; (c) Y. Apeloig, The chemistry of organic silicon compounds, Wiley, 1989.

2 (a) Y. Minami and T. Hiyama, Chem. Eur. J., 2019, 25, 391; (b) S. Bähr, W. Xue and M. Oestreich, ACS Catal., 2019, 9, 16; (c) M. Oestreich, E. Hartmann and M. Mewald, Chem. Rev., 2013, 113, 402; (d) L. Xu, L. Li, G. Lai and J. Jiang, Chem. Soc. Rev., 2011, 40, 1777; (e) T. H. Chan and D. Wang, Chem. Rev., 1992, 92, 995; (f) P. Xiao, L. Gao and Z. Song, Chem. Eur. J., 2019, 25, 2407; (g) A. Hameed, R. D. Alharthy, J. Iqbal and P. Langer, Tetrahedron, 2016, 72, 2763; (h) M. Greenhalgh, Springer International Publishing, Cham, 2016, pp. 33; (i) M. D. Greenhalgh, A. S. Jones and S. P. Thomas, ChemCatChem, 2015, 7, 190; (j) B. M. Trost and Z. T. Ball, Synthesis, 2005, 2005, 853; (k) M. G. Voronkov, V. M. Dyakov and S. V. Kirpichenko, J. Organomet. Chem., 1982, 233, 1; (I) I. Beletskaya and C. Moberg, Chem. Rev., 2006, 106, 2320; (m) M. A. Brook, Silicon in Organic, Organometallic, and Polymer Chemistry, Wiley, New York, 2000.

3 (a) J. P. Morken, in Comprehensive Organic Synthesis II, 2014, pp. 939; (b) I. Beletskaya and C. Moberg, Chem. Rev., 1999, 99, 3435; (c) M. B. Ansell, O. Navarro and J. Spencer, Coord. Chem. Rev., 2017, 336, 54; (d) M. Suginome and Y. Ito, J. Chem. Soc., Dalton Trans., 1998, 1925; (e) M. Suginome and Y. Ito, Chem. Rev., 2000, 100, 3221.

4 (a) T. Ohmura and M. Suginome, Bull. Chem. Soc. Jpn., 2009, 82, 29; (b) J.-J. Feng, W. Mao, L. Zhang and M. Oestreich, Chem. Soc. Rev., 2021, 50, 2010.

5 (a) S. Díez-González and S. P. Nolan, Acc. Chem. Res., 2008, 41, 349; (b) B. Marciniec, Comprehensive Handbook on Hydrosilylation, Pergamon, 1992; (c) B. Marciniec, Hydrosilylation, Springer, 2008; (d) B. Marciniec and J. Guliński, J. Organomet. Chem., 1993, 446, 15; (e) Y. Nakajima and S. Shimada, RSC Adv., 2015, 5, 20603; (f) A. K. Roy, in Adv. Organomet. Chem., Elsevier, 2007, pp. 1; (g) J. L. Speier, in Catalysis and Organic Syntheses: Advances in Organometallic Chemistry, Elsevier, 1979, pp. 407.

6 A. P. Cinderella, B. Vulovic and D. A. Watson, J. Am. Chem. Soc., 2017, 139, 7741.

7 J. Duan, K. Wang, G. L. Xu, S. Kang, L. Qi, X. Y. Liu and X. Z. Shu, Angew. Chem., Int. Ed., 2020, 59, 23083.

8 (a) M. Oestreich, G. Auer and B. Weiner, Synthesis, 2006, 2006, 2113; (b) A. Hensel and M. Oestreich, Chem. Eur. J., 2015, 21, 9062; (c) Y. Y. Kong and Z. X. Wang, Adv. Synth. Catal., 2019, 361, 5440; (d) B. Yang and Z.-X. Wang, Org. Lett., 2019, 21, 7965; (e) C. Chu, Y. Liang and G. Fu, J. Am. Chem. Soc., 2016, 138, 6404; (f) C. Fopp, E. Romain, K. Isaac, F. Chemla, F. Ferreira, O. Jackowski, M. Oestreich and A. PerezLuna, Org. Lett., 2016, 18, 2054; (g) D. Vyas and M. Oestreich, Chem. Commun., 2010, 46, 568; (h) M. Oestreich and B. Weiner, Synlett, 2004, 2139; (i) L. Zhang and M. Oestreich, Org. Lett., 2018, 20, 8061; (j) H. Azuma, K. Okano and H. Tokuyama, Chem. Lett., 2011, 40, 959. 9 Y. Morizawa, H. Oda, K. Oshima and H. Nozaki, Tetrahedron Lett., 1984, 25, 1163.

10 (a) C. K. Hazra and M. Oestreich, Org. Lett., 2012, 14, 4010; (b) A. Perez-Luna, M. Oestreich, C. Fopp, K. Isaac, E. Romain, F. Chemla, F. Ferreira and O. Jackowski, Synthesis, 2017, 49, 724.

11 (a) W. C. Still, J. Org. Chem., 1976, 41, 3063; (b) E. Yamamoto, S. Ukigai and H. Ito, Synlett, 2017, 28, 2460.

12 (a) P. Knochel, M. Schade, S. Bernhardt, G. Manolikakes, A. Metzger, F. Piller, C. Rohbogner and M. Mosrin, Beilstein J. Org. Chem., 2011, 7, 1261; (b) X. Wu, X. Li, W. Huang, Y. Wang, H. Xu, L. Cai, J. Qu and Y. Chen, Org. Lett., 2019, 21, 2453; (c) D. Wang, H. Niu, M. Xie, G. 
Qu, H. Wang and H. Guo, Org. Lett., 2014, 16, 262; (d) S. J. Edeson, E. J. M. Maduli, S. Swanson, P. A. Procopiou and J. P. A. Harrity, Eur. J. Org. Chem., 2016, 2016, 83; (e) A. Krasovskiy, V. Malakhov, A. Gavryushin and P. Knochel, Angew. Chem., Int. Ed., 2006, 45, 6040; (f) C. Feng, D. Cunningham, Q. Easter and S. Blum, J. Am. Chem. Soc., 2016, 138, 11156.

13 (a) X. Wang, F. Liu, Y. Li, Z. Yan, Q. Qiang and Z. Q. Rong, ChemCatChem, 2020, 12, 5022; (b) H.-J. Zhang, D. L. Priebbenow and C. Bolm, Chem. Soc. Rev., 2013, 42, 8540; (c) G. Boyce, S. Greszler, J. Johnson, X. Linghu, J. Malinowski, D. Nicewicz, A. Satterfield, D. Schmitt and K. Steward, J. Org. Chem., 2012, 77, 4503; (d) W. H. Moser, Tetrahedron, 2001, 57, 2065; (e) P. C. B. Page, S. S. Klair and S. Rosenthal, Chem. Soc. Rev., 1990, 19, 147; (f) A. G. Brook, Acc. Chem. Res., 1974, 7, 77.

14 (a) J. Feng and M. Oestreich, Angew. Chem., Int. Ed., 2019, 58, 8211; (b) J. Rong, R. Oost, A. Desmarchelier, A. Minnaard and S. Harutyunyan, Angew. Chem., Int. Ed., 2015, 54, 3038; (c) J. González, J. Santamaría and A. Ballesteros, Angew. Chem., Int. Ed., 2015, 54, 13678; (d) R. Lettan, C. Galliford, C. Woodward and K. Scheidt, J. Am. Chem. Soc., 2009, 131, 8805; (e) R. B. Lettan, T. E. Reynolds, C. V. Galliford and K. A. Scheidt, J. Am. Chem. Soc., 2006, 128, 15566.

15 (a) J. R. Schmink and S. W. Krska, J. Am. Chem. Soc., 2011, 133, 19574; (b) S. Ramgren and N. Garg, Org. Lett., 2014, 16, 824.

16 (a) X. Lu, J. Zhang, L. Xu, W. Shen, F. Yu, L. Ding and G. Zhong, Org. Lett., 2020, 22, 5610; (b) M. Sasaki, Y. Kondo, T. Moto-ishi, M. Kawahata, K. Yamaguchi and K. Takeda, Org. Lett., 2015, 17, 1280; (c) Y. Matsuya, K. Wada, D. Minato and K. Sugimoto, Angew. Chem., Int. Ed., 2016, 55, 10079; (d) M. Decostanzi, J. Godemert, S. Oudeyer, V. Levacher, J.-M. Campagne and E. Leclerc, Adv. Synth. Catal., 2016, 358, 526.

17 (a) D. Priebbenow, J. Org. Chem., 2019, 84, 11813; (b) F. Tang, P.-J. Ma, Y. Yao, Y.-J. Xu and C.-D. Lu, Chem. Commun., 2019, 55, 3777; (c) H. J. Zhang, P. Becker, H. Huang, R. Pirwerdjan, F. F. Pan and C. Bolm, Adv. Synth. Catal., 2012, 354, 2157; (d) K. Ito, H. Tamashima, N. Iwasawa and H. Kusama, J. Am. Chem. Soc., 2011, 133, 3716; (e) M. Sasaki, Y. Kondo, M. Kawahata, K. Yamaguchi and K. Takeda, Angew. Chem., Int. Ed., 2011, 50, 6375; (f) J. Chen, C. Ding, W. Liu, X. Hou and L. Dai, J. Am. Chem. Soc., 2010, 132, 15493; (g) R. Unger, F. Weisser, N. Chinkov, A. Stanger, T. Cohen and I. Marek, Org. Lett., 2009, 11, 1853; (h) S. N. Greszler and J. S. Johnson, Org. Lett., 2009, 11, 827; (i) R. Lettan, C. Woodward and K. Scheidt, Angew. Chem., Int. Ed., 2008, 47, 2294; (j) Y. Obora, Y. Ogawa, Y. Imai, T. Kawamura and Y. Tsuji, J. Am. Chem. Soc., 2001, 123, 10489; (k) K. Takeda, M. Fujisawa, T. Makino, E. Yoshii and K. Yamaguchi, J. Am. Chem. Soc., 1993, 115, 9351; (I) H. J. Reich, J. J. Rusek and R. E. Olson, J. Am. Chem. Soc., 1979, 101, 2225; (m) A. G. Brook, J. Am. Chem. Soc., 1958, 80, 1886; (n) N. Lee, C.-H. Tan and D. Leow, Asian J. Org. Chem., 2019, 8, 25.

18 (a) K. Jahyo, L. Jae Hyoung, K. Koan Seong, J. Jae Uk and P. Chongsuh, Tetrahedron Lett., 1987, 28, 3261; (b) J. P. Picard, R. Calas, J. Dunogues, N. Duffaut, J. Gerval and P. Lapouyade, J. Org. Chem., 1979, 44, 420; (c) I. Fleming and U. Ghosh, J. Chem. Soc., Perkin Trans. 1, 1994, 257; (d) A. Capperucci, A. Degl'Innocenti, C. Faggi, A. Ricci, P. Dembech and G. Seconi, J. Org. Chem., 1988, 53, 3612; (e) B. F. Bonini, M. Comes-Franchini, G. Mazzanti, U. Passamonti, A. Ricchi and P. Zani, Synthesis, 1995, $1995,92$.

19 (a) K. Yamamoto, S. Suzuki and J. Tsuji, Tetrahedron Lett., 1980, 21, 1653; (b) K. Yamamoto, A. Hayashi, S. Suzuki and J. Tsuji, Organometallics, 1987, 6, 974.

20 F. Geng and R. E. Maleczka Jr, Tetrahedron Lett., 1999, 40, 3113.

21 (a) B. Wu and R. Zhu, ACS Catal., 2020, 10, 510; (b) X. Deng, G. Zhou, J. Tian and R. Srinivasan, Angew. Chem., Int. Ed., 2020, 22, 7024.

22 A. Kunai, T. Sakurai, E. Toyoda, M. Ishikawa and Y. Yamamoto, Organometallics, 1994, 13, 3233.

23 (a) L. Zhu, R. M. Wehmeyer and R. D. Rieke, J. Org. Chem., 1991, 56, 1445; (b) E. Erdik, Tetrahedron, $1987,43,2203$.

24 M. S. Newman and F. J. Evans, J. Am. Chem. Soc., 1955, 77, 946.

25 (a) G. Picotin and P. Miginiac, J. Org. Chem., 1987, 52, 4796; (b) J. K. Gawroński, Tetrahedron Lett., 1984, $25,2605$.

26 S. Huo, Org. Lett., 2003, 5, 423.

27 (a) K. Takagi, Chem. Lett., 1993, 22, 469; (b) K. Takagi, Y. Shimoishi and K. Sasaki, Chem. Lett., 1994, 23, 2055; (c) R. F. Abdulla, Aldrichim. Acta, 1988, 21, 31.

28 M. Bellassoued, M. Gaudemar, A. El Borgi and B. Baccar, J. Organomet. Chem., 1985, 280, 165.

29 R. Goddard, C. Krüger, N. A. Ramadan and A. Ritter, Angew. Chem., Int. Ed., 1995, 34, 1030.

30 V. Murugesan, V. Balakrishnan and R. Rasappan, J. Catal., 2019, 377, 293.

31 T. N. Majid and P. Knochel, Tetrahedron Lett., 1990, 31, 4413.

32 K. Takagi, N. Hayama and S. Inokawa, Bull. Chem. Soc. Jpn., 1980, 53, 3691.

33 (a) C. Gosmini, M. Amatore, S. Claudel and J. Périchon, Synlett, 2005, 2171; (b) I. Kazmierski, C. Gosmini, J.-M. Paris and J. Périchon, Tetrahedron Lett., 2003, 44, 6417.

34 (a) D. S. Ziegler, K. Karaghiosoff and P. Knochel, Angew. Chem., Int. Ed., 2018, 57, 6701; (b) M. Balkenhohl, D. Ziegler, A. Desaintjean, L. Bole, A. Kennedy, E. Hevia and P. Knochel, Angew. Chem., Int. Ed., 2019, 58, 12898.

35 C. A. Malapit, J. R. Bour, S. R. Laursen and M. S. Sanford, J. Am. Chem. Soc., 2019, 141, 17322.

36 (a) J. Hu, H. Wu, C. Li, W. Sheng, Y. Jia and J. Gao, Chemistry, 2011, 17, 5234; (b) R. Jana, T. Pathak and M. Sigman, Chem. Rev., 2011, 111, 1417.

37 (a) G. Schwarzwalder, C. Matier and G. Fu, Angew. Chem., Int. Ed., 2019, 58, 3571; (b) R. Soler-Yanes, I. Arribas-Álvarez, M. Guisán-Ceinos, E. Buñuel and D. J. Cárdenas, Chem. Eur. J., 2017, 23, 1584; (c) A. Oelke, J. Sun and G. Fu, J. Am. Chem. Soc., 2012, 134, 2966; (d) V. Phapale, E. Buñuel, M. García-Iglesias and D. Cárdenas, Angew. Chem., Int. Ed., 2007, 46, 8790; (e) G. Jones, J. Martin, C. McFarland, O. Allen, R. Hall, A. Haley, R. Brandon, T. Konovalova, P. Desrochers, P. Pulay and D. Vicic, J. Am. Chem. Soc., 2006, 128, 13175.

38 J. G. Smith, S. E. Drozda, S. P. Petraglia, N. R. Quinn, E. M. Rice, B. S. Taylor and M. Viswanathan, J. Org. Chem., $1984,49,4112$. 39 R. Moser, T. Nishikata and B. H. Lipshutz, Org. Lett., 2009, 12, 28.

40 (a) L. T. Ball, M. Green, G. C. Lloyd-Jones and C. A. Russell, Org. Lett., 2010, 12, 4724; (b) L. T. Ball, G. C. Lloyd-Jones and C. A. Russell, Chem. Eur. J., 2012, 18, 2931; (c) J. Xie, K. Sekine, S. Witzel, P. Krämer, M. Rudolph, F. Rominger and A. S. K. Hashmi, Angew. Chem., Int. Ed., 2018, 57, 16648; (d) K. Gondo, J. Oyamada and T. Kitamura, Org. Lett., 2015, 17, 4778; (e) M. J. Harper, E. J. Emmett, J. F. Bower and C. A. Russell, J. Am. Chem. Soc., 2017, 139, 12386; (f) W. E. Brenzovich, J.-F. Brazeau and F. D. Toste, Org. Lett., 2010, 12, 4728; (g) M. Shibata, H. Ito and K. Itami, J. Am. Chem. Soc., 2018, 140, 2196; (h) K. Funaki, T. Sato and S. Oi, Org. Lett., $2012,14,6186$.

41 (a) A. Postigo and R. A. Rossi, Org. Lett., 2001, 3, 1197; (b) H. Guo, X. Chen, C. Zhao and W. He, Chem. Commun., 2015, 51, 17410; (c) K. Hitoshio, H. Yamagishi, J. Shimokawa and H. Yorimitsu, Chem. Commun., 2021, 57, 6867; (d) T. Nagata, T. Inoue, X. Lin, S. Ishimoto, S. Nakamichi, H. Oka, R. Kondo, T. Suzuki and Y. Obora, RSC Adv., 2019, 9, 17425; (e) E. Shirakawa, T. Kurahashi, H. Yoshida and T. Hiyama, Chem. Commun., 2000, 1895.

42 (a) G. Auer and M. Oestreich, Chem. Commun., 2006, 311; (b) J. M. O'Brien and A. H. Hoveyda, J. Am. Chem. Soc., 2011, 133, 7712; (c) A. Vaughan and R. D. Singer, Tetrahedron Lett., 1995, 36, 5683; (d) C. Walter, G. Auer and M. Oestreich, Angew. Chem., Int. Ed., 2006, 45, 5675; (e) T. Kitanosono, L. Zhu, C. Liu, P. Xu and S. Kobayashi, J. Am. Chem. Soc., 2015, 137, 15422; (f) K.-s. Lee and A. H. Hoveyda, J. Am. Chem. Soc., 2010, 132, 2898. 
43 M. Takeda, K. Yabushita, S. Yasuda and H. Ohmiya, Chem. Commun., 2018, 54, 6776. 44 D. Ni and M. K. Brown, ACS Catal., 2021, 11, 1858. 